\title{
Sediment budget quantification of a sub-Alpine river catchment since the end of the last glaciation
}

\author{
Elodie Brisset ${ }^{\mathrm{a}, \mathrm{b}, *}$, Cécile Miramont ${ }^{\mathrm{a}}$, Edward J. Anthony ${ }^{\mathrm{b}, 1}$, Hélène Bruneton ${ }^{\mathrm{b}}$, \\ Thierry Rosique ${ }^{c}$, Olivier Sivan ${ }^{\mathrm{d}}$ \\ a Institut Méditerranéen de Biodiversité et d'Ecologie marine et continentale (IMBE), UMR-7263 CNRS, Aix-Marseille University, Europôle Méditerranéen de l'Arbois, \\ BP 80, 13545 Aix-en-Provence cedex 04, France \\ ${ }^{\mathrm{b}}$ Aix-Marseille University, Centre Européen de Recherche et d'Enseignement des Géosciences de l'Environnement (CEREGE) UM 34, Europôle Méditerranéen de l'Arbois, \\ BP 80, 13545 Aix-en-Provence cedex 04, France \\ c Laboratoire Image, Ville, Environnement (LIVE), ERL 7230, Faculté de géographie et d'aménagement, Strasbourg University, 3 rue de l'Argonne, 67083 Strasbourg, France \\ d Inrap Méditerranée, UMR 7264, 105 rue Serpentine, ZA les Jalassières, 13510 Eguilles, France
}

Keywords:

River sediment budget

Source-to-sink

Catchment erosion rate

Badlands

Holocene

Mediterranean mountain landscape

\begin{abstract}
A B S T R A C T
Changes in sediment budget and quantification of sediment fluxes of a small $\left(5.3 \mathrm{~km}^{2}\right)$ Mediterranean subAlpine river catchment (Charanc catchment, Southern French Alps, $44^{\circ} 30^{\prime} 44 \mathrm{~N} / 5^{\circ} 51^{\prime} 55 \mathrm{E}$ ) are estimated for the last 20,000 years using a GIS-based approach and 3D palaeotopographic reconstructions. Following field surveys, a high-resolution morphometric map was established. Ten ${ }^{14} \mathrm{C}$ ages of sub-fossil trees and charcoal beds were compiled. All datasets were integrated into a Geographic Information System. We computed three palaeosurfaces by masking the Digital Elevation Model of the current topography, and calculated the sediment budget of the catchment. Estimations of specific hillslope erosion, sedimentation and export rates highlight the evolution of the catchment and its sensitivity to variations in the ratio of sediment load to stream discharge. Between 20,000 and 14,500 cal. BP, sediment that was eroded ( 37 million $\mathrm{m}^{3}$ ) within the Charanc catchment was entirely exported. A change to a sedimentation regime commenced at around 14,500 cal. BP. Between $9000 \mathrm{cal}$. BP and $7000 \mathrm{cal}$. BP, footslopes were buried by fan-shaped deposits at a rate of $6700 \mathrm{~m}^{3} / \mathrm{yr}$. Since $7000 \mathrm{cal}$. BP, the overall morphogenetic regime has been one of vertical incision. $73 \%$ of the material eroded over the last 14,500 years $\left(14\right.$ million $\mathrm{m}^{3}$ ) was stored in fan-shaped deposits. At the present time, $46 \%$ of this volume $\left(6 \mathrm{million}^{3}\right)$ is still stored in the catchment. 8 million $\mathrm{m}^{3}$ of sediments have thus been exported out of the Charanc catchment since 14,500 cal. BP. Annual specific erosion rates on marly slopes are estimated at: (1) 98 to $111 \mathrm{t} / \mathrm{ha} / \mathrm{yr}$ for the period $20,000-14,500$ cal. BP, which is comparable to present rates measured on denudated marls in the Southern French Alps, under a probably climate-driven erosion regime, and (2) 17 to 20 t/ha/yr since 14,500 cal. BP, a reduction in erosion rate that may have been favoured by a more extensively wooded landscape.
\end{abstract}

\section{Introduction}

Soil erosion and sediment deposition have strongly determined Mediterranean mountain landscape development during the Holocene, especially in erosion-sensitive areas characterised by a marly sub-stratum. Widespread rill erosion processes have progressively shaped these landscapes, generating large-scale development of badlands and corresponding high sediment yields in valleys (Bryan and Yair, 1982). Studies aimed at quantifying such sediment yields have generally been conducted using geomorphic and sedimentary data (e.g., Torri et al., 2000), including in the Mediterranean basin (Gallart et al.,

\footnotetext{
* Corresponding author at: IMBE/CEREGE Institutes, Aix-Marseille University, Europôle Méditerranéen de l'Arbois, Bâtiment Villemin, BP 80, 13545 Aix-en-Provence cedex 04, France. Tel.: + 33442908484 .

E-mail address: brisset@cerege.fr (E. Brisset).

${ }^{1}$ Institut Universitaire de France, France.
}

2002). Nadal-Romero et al. (2011) recently showed the high variability of sediment yield in Mediterranean catchments and the complex relationship between such yield and catchment size. They determined yield values ranging from $9.3 \mathrm{t} / \mathrm{ha} / \mathrm{yr}$ to $475 \mathrm{t} / \mathrm{ha} / \mathrm{yr}$. These various studies concern short timescales (days, years or decade), and also show that erosion rates are strongly influenced by climatic and land-use changes. In the present-day context of: (1) global warming, expected to lead to an increase in the frequency and/or intensity of extreme precipitation events liable to generate torrential floods, especially in the Mediterranean region (Giorgi and Lionello, 2008; IPCC et al., 2007), and (2) increase in vegetation cover due to rural exodus, there is a need for contextualising fluvial sediment dynamics within the longer-term Late Pleistocene to Holocene framework.

Only a few studies have attempted to quantify sediment budgets, soil losses and sediment storage over long (centennial or millennial) timescales, mainly because of the difficulty of dating accurately sediment infills, the preservation of which, moreover, may be poor and/or 


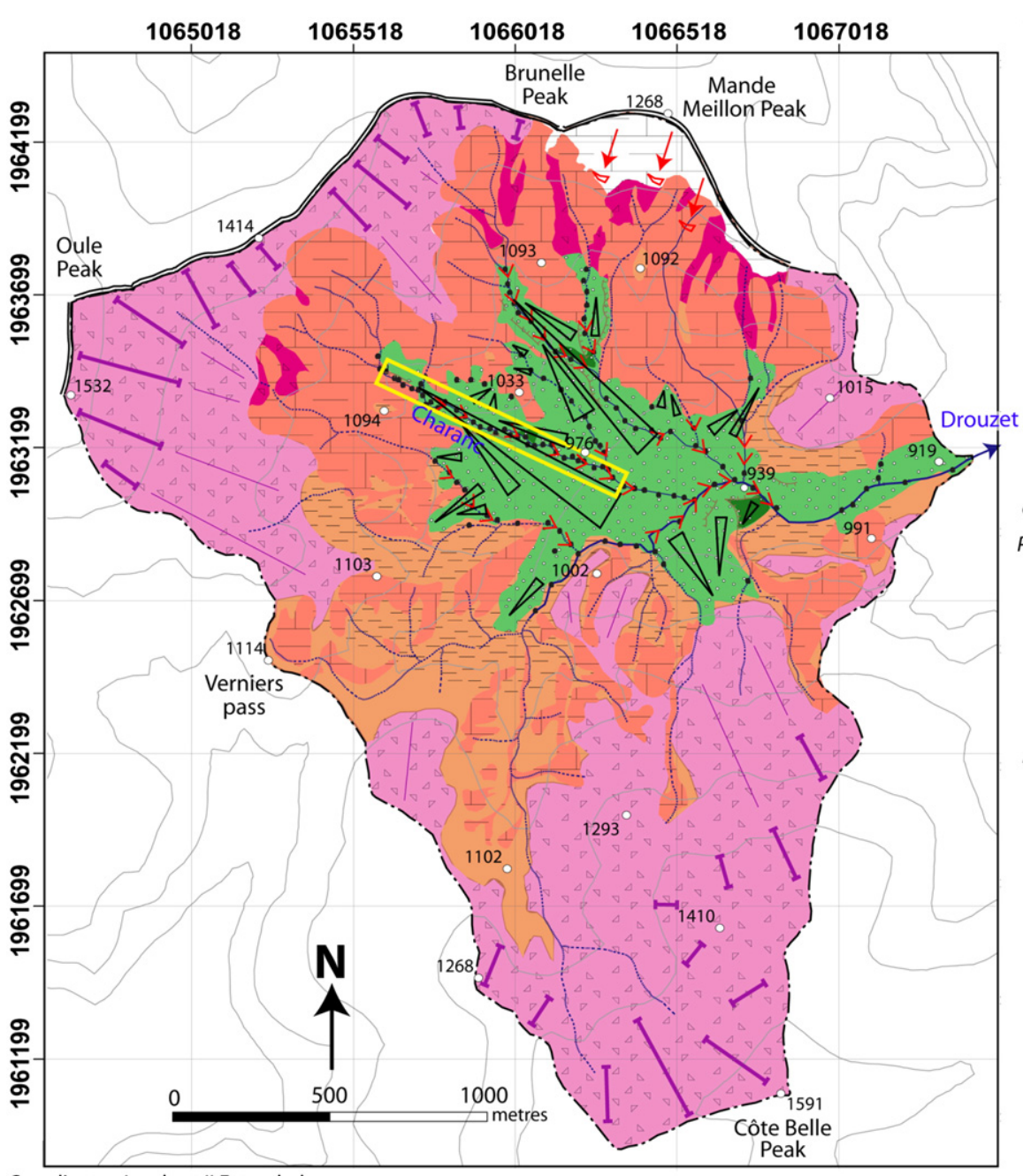

Topography

Elevation contours (50 m interval)

1268 Elevation point $(\mathrm{m})$

Mountain crest line

Escarpment

\section{Hydrological network}

$\longrightarrow$ Perenial flow

Intermittent flow

\section{Lithology}

\section{$\square$ Tithonic limestones \\ Marly limestones}

\section{Geomorphology}

Periglacial forms and processes

III Regularised slopes

Glacis
Upper level MIS-6 deposits
Lower level MIS-2 deposits

Lateglacial to Holocene forms and processes

$D$ Coalescent fan-shaped glacis

Terrace 1

Terrace 2 (Main Postglacial Infilling)

Erosion processes

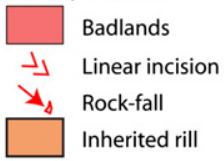

Coordinates: Lambert II Extended

Fig. 3. GIS-integrated geomorphological map of the Charanc catchment.

a threat to the numerous hydropower reservoirs as a result of the rapid rates of infilling of artificial dams and of the Berre Lagoon in the Mediterranean, to which water and sediments from the Durance have been diverted by a canal (Imbert et al., 1999) (Fig. 1).

Although erosion processes represent a crucial problem in the Southern French Alps, sediment budgets have never been considered over long timescales. We present here a multimillennial-scale study of alluvial sediment storage in, and export from, a small river catchment (the Charanc River), one of the numerous small feeder catchments in the Middle Durance basin (Fig. 1). Based on field measurements and data-feed into a Geographic Information System, we analyse the Charanc catchment in order to: (1) identify and map incision and deposition processes over the last 20,000 years, (2) characterise and quantify the sediment budget, and (3) provide an interpretation of the catchment palaeo-environmental evolution.

\section{Study site and previous work}

The Charanc catchment $\left(5.3 \mathrm{~km}^{2}, 44^{\circ} 30^{\prime} 44 \mathrm{~N} / 5^{\circ} 51^{\prime} 55 \mathrm{E}\right)$ is located between two peaks, Oule and Côte Belle (Fig. 1), and ranges in elevation from 500 to $1600 \mathrm{~m}$ above sea level. The catchment drains the southern slopes of the former peak and the northern slopes of the latter. These peaks form an inverted relief consisting of synclines of resistant Tithonian limestones overlying "Black Earths" incised by the Charanc
(Figs. 2a, 3). Flow in the Charanc is intermittent and feeds into the Drouzet torrent, a tributary of the Petit Buëch, which, in turn, flows into the Durance River. In the highest part of the Charanc catchment, regularised slopes ranging from 1400 to $1100 \mathrm{~m}$ are sparsely vegetated by Scots pines and pubescent oaks interspersed in a shrubby matrix (Fig. 2a). Badlands characterised by sharp and narrow ridges and by numerous deep valley incisions are particularly widespread in the basin. These landforms are particularly common in the "Black Earths" and on south-facing slopes. Downstream, cultivated land and pastures cover most of the valley. Mean annual precipitation in the study area is $800 \mathrm{~mm}$ and is concentrated from early October to late May. A pronounced dry season occurs from June to September. Rainfall is very irregularly distributed both inter-annually and throughout the year, falling in torrential high-intensity downpours that favour high erosion rates. Snowfall generally begins in October, and snowmelt ends in late April. Intense freeze-thaw processes on sun-exposed south-facing slopes also contribute to the high sediment yields (Rovera and Robert, 2005).

The marked incision in the Charanc catchment has resulted in the exposure of numerous outcrops (Fig. 4). Previous studies on these outcrops have enabled the reconstruction of geomorphic changes since the Pleistocene (Miramont et al., 2008; Rosique, 1996; Sivan, 2002). These authors identified a palaeo-environment similar to that of dozens of other well-dated sites in the Middle Durance basin (Gautier, 1992; 
Table 1

Synthesis of ${ }^{14} \mathrm{C}$ ages defining the age of the modelled palaeotopography.

\begin{tabular}{|c|c|c|c|c|c|c|c|}
\hline Lab. code & Age BP & Error BP (1 sigma) & Years cal. BP (2 sigma) & Dated material & Specie identification & Reference & No. (see Fig. 4) \\
\hline AA10222 & 8290 & 70 & $9040-9465$ & Sub-fossil wood & Pinus sylvestris sp. & Sivan (2002) & 1 \\
\hline AA10226 & 6895 & 100 & $7580-7930$ & Charcoal & P. sylvestris sp. & Sivan (2002) & 2 \\
\hline AA10224 & 8145 & 70 & $8790-9400$ & Sub-fossil wood & P. sylvestris sp. & Sivan (2002) & 3 \\
\hline AA10223 & 7685 & 70 & $8380-8590$ & Sub-fossil wood & P. sylvestris sp. & Sivan (2002) & 4 \\
\hline LGQ998 & 8110 & 250 & $8435-9530$ & Charcoal & P. sylvestris sp. & Rosique (1996) & 5 \\
\hline LGQ1076 & 5240 & 190 & $5605-6400$ & Sub-fossil wood & P. sylvestris sp. & Rosique (1996) & 6 \\
\hline AA10225 & 8755 & 75 & $9545-10,145$ & Sub-fossil wood & P. sylvestris sp. & Sivan (2002) & 7 \\
\hline LGQ1075 & 6920 & 190 & $7435-8155$ & Sub-fossil wood & P. sylvestris sp. & Rosique (1996) & 8 \\
\hline LGQ1074 & 7300 & 210 & $7690-8515$ & Sub-fossil wood & P. sylvestris sp. & Rosique (1996) & 9 \\
\hline LGQ997 & 7250 & 140 & $7800-8365$ & Sub-fossil wood & P. sylvestris sp. & Rosique (1996) & 10 \\
\hline Н 27378 & 12,500 & 30 & $14,220-15,055$ & Sub-fossil wood & P. sylvestris sp. & Kaiser et al (2012) & 11 \\
\hline GrN 26628 & 12,000 & 60 & $13,720-14,020$ & Sub-fossil wood & P. sylvestris sp. & Sivan (2002) & 12 \\
\hline
\end{tabular}

Table 2

Estimation of volume error.

\begin{tabular}{ll}
\hline Compartment & Estimated error \\
\hline From 20,000 to 14,500 cal. BP eroded volume & $6.50 \%$ \\
From 14,500 to Present eroded volume & $8.10 \%$ \\
From 14,500 to 6000 cal. BP Main Postglacial Infilling & $7.30 \%$ \\
Vertical incision post-6000 cal. BP & $8.90 \%$ \\
\hline
\end{tabular}

From 11,800 to about 7000 cal. BP, deposition rates increased rapidly, leading to sediment encroachment on the neighbouring hillslopes in the upstream catchment segments (colluvial MPI). This sedimentation phase is dominated by loamy to gravelly material. In the Charanc catchment, these widespread deposits form coalescent fan-shaped glacis (Figs. 2b, 3). This sedimentary infill attains a thickness of up to $30 \mathrm{~m}$ on the bordering catchment slopes but peters out to about $1 \mathrm{~m}$ above the bed of the stream just $500 \mathrm{~m}$ downstream. Outcrops highlight different sequences of torrential sedimentation representing a succession of flood deposits just above the marly substrate (Fig. 4). The deposits are mainly (60\%) composed of calcareous medium to coarse stratified gravels, the diameter of which ranges from a few centimetres to tens of centimetres. The gravels are poorly sorted, sub-angular, and interbedded with clayey-muddy lenses. The onset of the sedimentation sequence is dated from sub-fossil pines (nos. 1, 3, 5 and 7) at about 9000 cal. BP (Fig. 4 and Table 1). Radiocarbon ages from sub-fossil pines (no. 4 located $10 \mathrm{~m}$ above the sub-stratum and from nos. 2 and 8 in the top part of these deposits) show that sedimentation lasted until at least around $7500 \mathrm{cal}$. BP. The MPI in the Charanc basin was incised thereafter. This down-cutting phase is highlighted by remnants of a $3 \mathrm{~m}$-thick lower terrace found below the surface of the MPI (Fig. 4). This thin terrace contains a sub-fossil tree (no. 6) dated at $5240 \pm 190 \mathrm{BP}$ (56006400 cal. BP).

Thus, the linear incision phase following the MPI is constrained in the Charanc between the upper part of the MPI at ca. 7500 and the lower terrace at ca. 6000 years cal. BP (Fig. 4). This geomorphic trend is an important change observed in all the tributaries of the Durance River (Fig. 5). Following this major erosion phase, incision has persisted up to the present time in most of the catchments. In some of these catchments, one or more thin alluvial gravel-rich terraces were formed, encased in the MPI. These thin deposits do not attain the prominence of the MPI in the landscape. Considering all the radiocarbon ages obtained in the other sites and the fact that pine no. 2 dated near the top of the
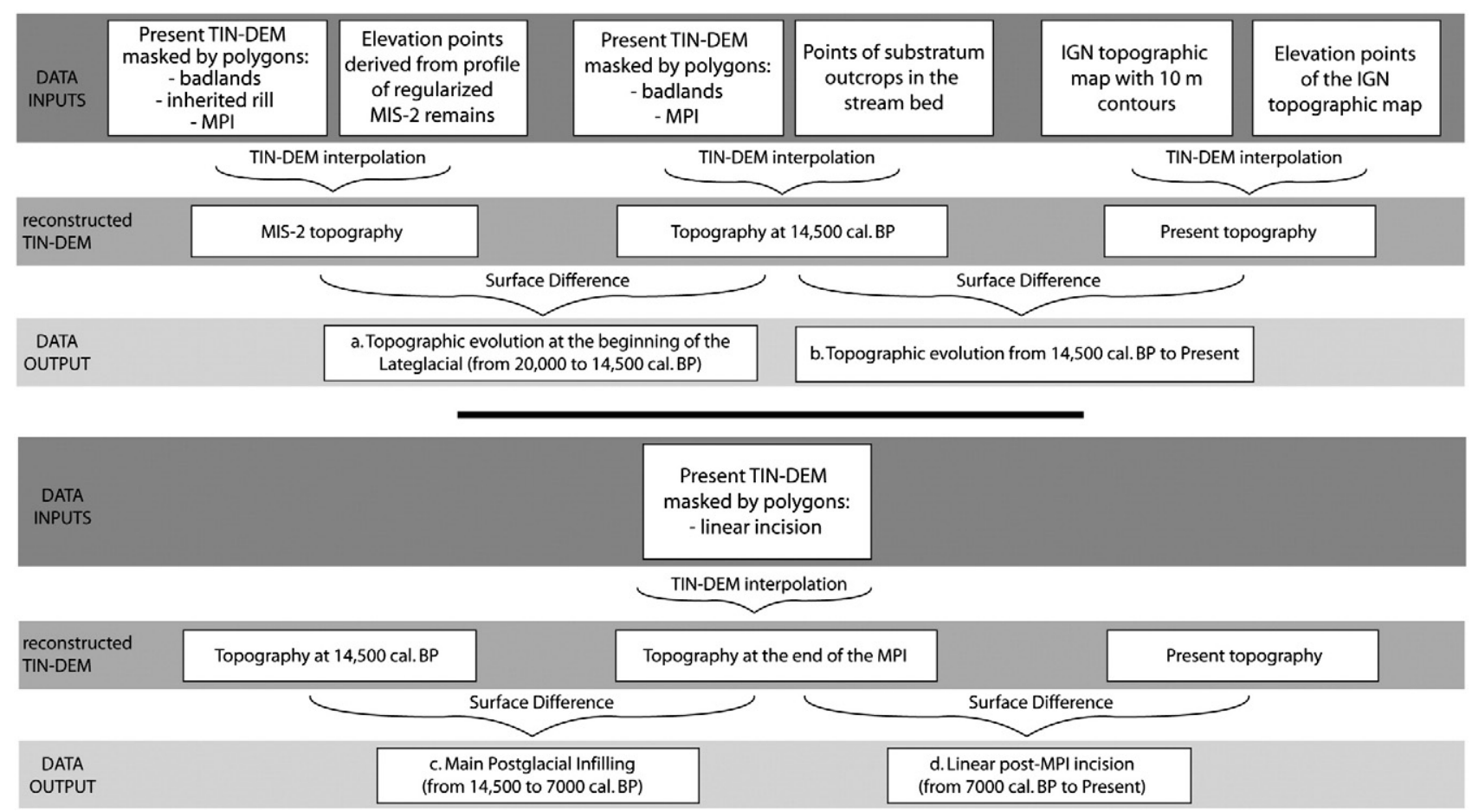

Fig. 6. Flowchart for palaeotopography reconstructions and for calculating the Postglacial sediment budget. 

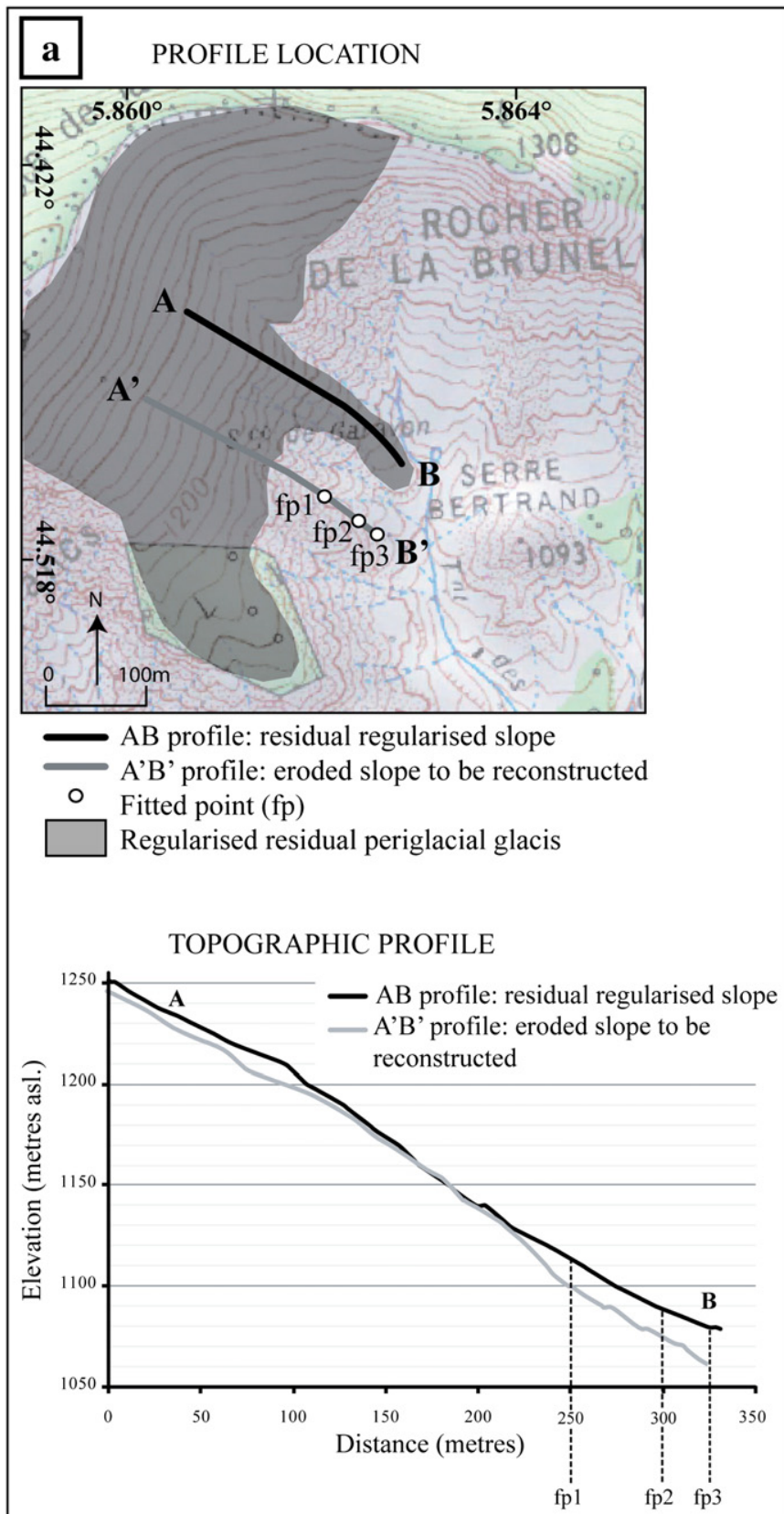

Eroded slope to be reconstructed (A'B') fitted to the residual regularised slope $(\mathrm{AB})$

$\mathrm{fp} 1(\mathrm{AB})=\mathrm{fp} 1\left(\mathrm{~A}^{\prime} \mathrm{B}^{\prime}\right)+10$ metres

fp2 $(A B)=f p 2\left(A^{\prime} B^{\prime}\right)+17$ metres

$\mathrm{fp} 3(\mathrm{AB})=\mathrm{fp} 3\left(\mathrm{~A}^{\prime} \mathrm{B}^{\prime}\right)+20$ metres

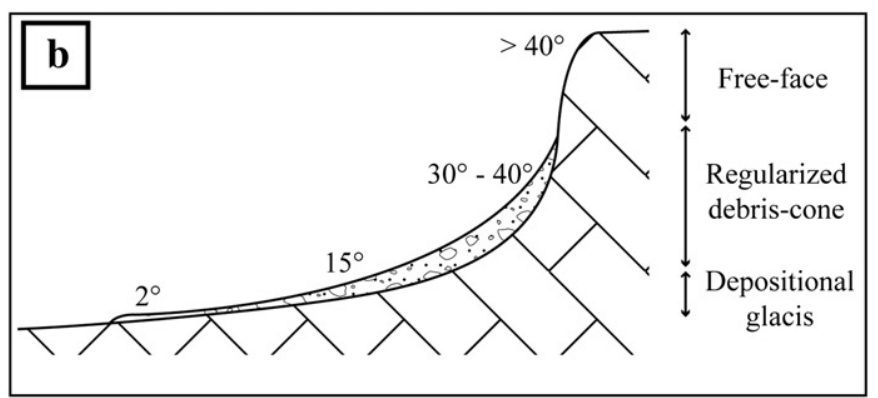

Fig. 7. (a) Regularised slope reconstruction, (b) typical periglacial slope segments according to the King profile (French, 2007).
MPI is buried under a 3 m-thick deposit, we have retained a simplified age of 7000 cal. BP for the end of the MPI in the Charanc catchment.

\section{Methods}

The spatial sediment budget pattern and its quantification were determined through 3D palaeotopographic reconstructions using a GIS compilation of the extensive datasets from surveys conducted by Rosique (1996) and Sivan (2002), topographical maps, aerial photographs, and new field investigations.

\subsection{Geomorphic mapping and palaeotopographic modelling}

GPS-assisted field investigations were conducted in order to delineate in the field all inherited surfaces of the Charanc catchment. These are symbolised by polygons in the GIS (Fig. 3). Field observations from outcrops were mapped using their $\mathrm{x}, \mathrm{y}$, and $\mathrm{z}$ coordinates. The topographic data were managed using Spatial Analyst tools in ArcGIS. Triangulated irregular network (TIN-DEM) interpolations were preferred to regular grid methods such as filtering techniques because the TINDEM method preserves the original irregular distribution of data nodes plotted in the field (Peucker et al., 1978). Regular grid methods would imply resolving the degree of aggregation of data (an optimal filtering coefficient), which depends on terrain roughness. Such terrain roughness cannot be determined in case of inherited surfaces. Three Digital Elevation Models (DEM) of the catchment palaeotopography were reconstructed at different key-dates of the morphogenetic evolution corresponding to major geomorphic trends recognised in the Charanc catchment and over the entire Durance basin (Fig. 5):

- a TIN-DEM of the topography at the end of the Pleistocene around 20,000 cal. BP (the initial state),

- a TIN-DEM of the topography at 14,500 cal. BP (before the MPI),

- a TIN-DEM of the topography at the end of the MPI at $7000 \mathrm{cal}$. BP.

Since at each key-date the density of topographic information is not regular in space, accuracy of the reconstructed palaeotopographies varies through time. The accuracy of a reconstructed DEM depends on: (1) the resolution of the modern topography DEM, and (2) the density of field-derived points. The modern topography was constructed by digitising all elevation contours of the map with the highest resolution available for the study area: horizontal and vertical accuracies are respectively $2.5 \mathrm{~m}$ and $10 \mathrm{~m}$ (1:25,000 topographic map of Serres/Veynes georeferenced in Lambert II Extended, and provided by IGN, 2005). A total of 125 elevation field-points were established to constrain the palaeotopographies, but exclusively for sub-stratum outcrops in the streambed. Hence, palaeotopographic reconstructions are better constrained along the hydrological network than elsewhere in the catchment. When extrapolating elevations points, it is assumed that the erosion and deposition geometry mapped in the field is representative of the whole surface. Based on field geomorphic observations, we defined a reasonable error range of $\pm 10 \mathrm{~m}$ in the elevation of the palaeotopography envelope to calculate the error range of the final volumes (Table 2). The TIN-DEM of the current topography has been converted into a point grid. The final palaeotopography was reconstructed based on the steps described below and synthetised in Fig. 6.

\subsubsection{TIN-DEM of the topography at the MIS-2 around 20,000 cal. BP (initial state)}

We first modelled the abandonment surface of the periglacial accumulation glacis (attributed to the end of the Pleniglacial period (MIS2)) where the latter have been eroded over the last 20 millennia. The TINDEM of the current topography was masked by polygons corresponding to areas of: (1) generalised rill erosion, (2) inherited rill erosion, and (3) the MPI. 
a) State of the basin at the MIS-2

Regularised slopes

(around 20,000 cal. BP)

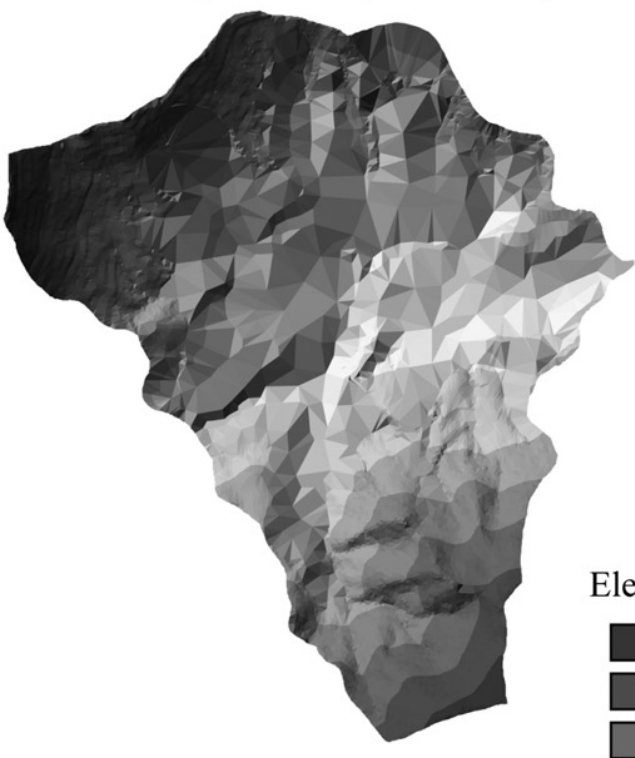

c) State of the basin at the end of the MPI*

(at 7000 cal. BP)

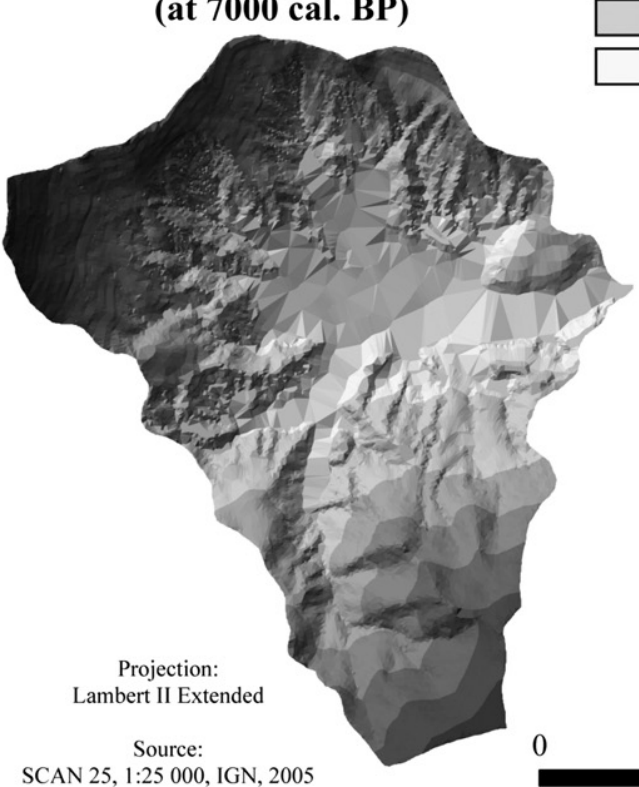

25, 1:25 000, IGN, 2005 b) State of the basin at 14,500 cal. BP Initial phase of basin erosion

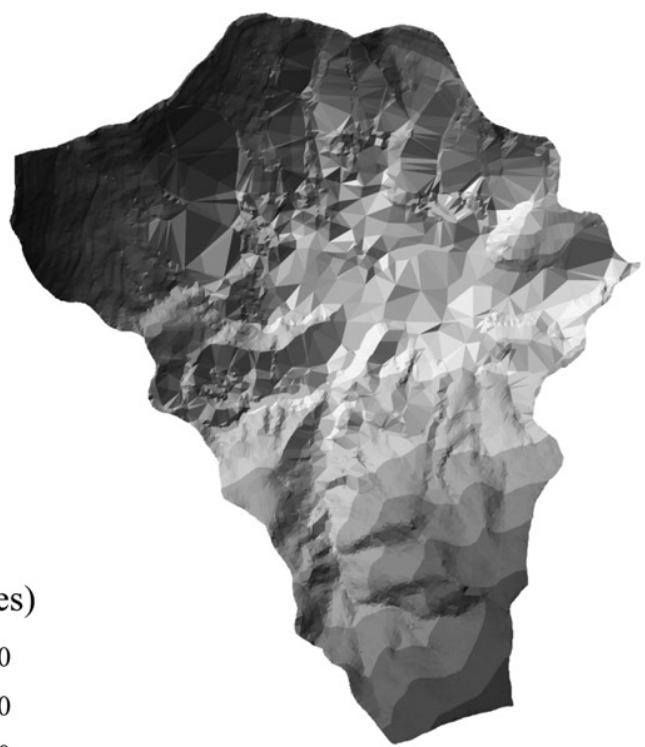

d) Present state of the basin (after stream linear incision $1100-1200$ $1000-1100$ $919-1000$

$1400-1500$

$1300-1400$

$1200-1300$ into the MPI*)

Elevation (metres)
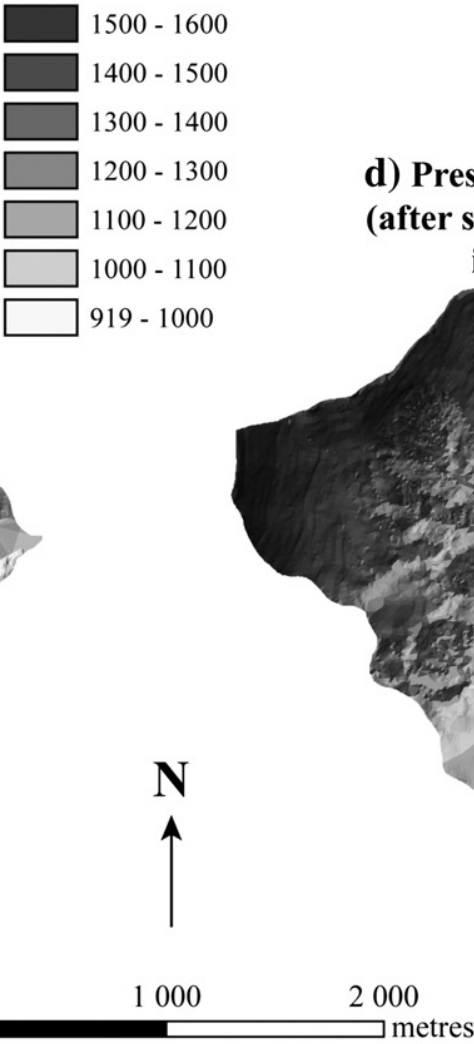

Fig. 8. Digital Elevation Models (DEMs) of three reconstructed (a-c) and the present (d) topographies of the Charanc catchment over the Postglacial period.

The method adopted to reconstruct the eroded regularised slopes involves the following:

- In the upper part of the catchment, profiles cutting through the residual regularised periglacial surface were established and then plotted on a graph with theoretical profiles drawn across the eroded zones as shown in Fig. 7a.

- In the lower part of the catchment, where no residual periglacial deposits are preserved, a set of current topographic profiles were measured for the entire catchment area. Borders of the periglacial remnants were plotted on these profiles and extended down to the valley following the periglacial type profile (King model, French, 2007), the slope of which decreases downstream (Fig. 7b). The elevation of the valley bottom around 20,000 cal. BP was defined from the intersection of all the profiles.

The points of regularised residual periglacial remnants were then interpolated with the reconstructed points.

\subsubsection{TIN-DEM of the topography at $14,500 \mathrm{cal}$. BP (before the MPI)}

This palaeosurface had to be reconstructed in order to replicate the state of the catchment before dismantling of the periglacial slopes at around 14,500 cal. BP. We consider that large-scale incision had already affected the Charanc catchment at this time. The TIN-DEM of the current topography was masked by polygons of the sub-stratum beneath the MPI. The steps to compute this palaeotopography were: 
- masking of the TIN-DEM of the topography at the end of the Pleistocene period using the polygon of the MPI surface,

- addition of the elevation points, plotted in the field (GPS-field survey points in Fig. 3), of sub-stratum outcrops in the stream bottom beneath the MPI before re-interpolation.

\subsubsection{TIN-DEM of the topography at the end of the MPI}

The topography to be reconstructed here corresponded to the MPI abandonment surface prior to the linear incision of the torrential network. The TIN-DEM of the current topography was masked by polygons corresponding to this incision before the re-interpolation.

\subsection{Quantification of sediment erosion and deposition}

The results of elevation subtractions between TIN-DEMs represent the eroded and deposited sediment volumes in cubic metres for each compartment per period. This was obtained using the "Surface Difference" 3D Analyst module, the outputs of which were then mapped as a) Topographic evolution at the beginning of the Lateglacial (from 20,000 to 14,500 cal. BP)

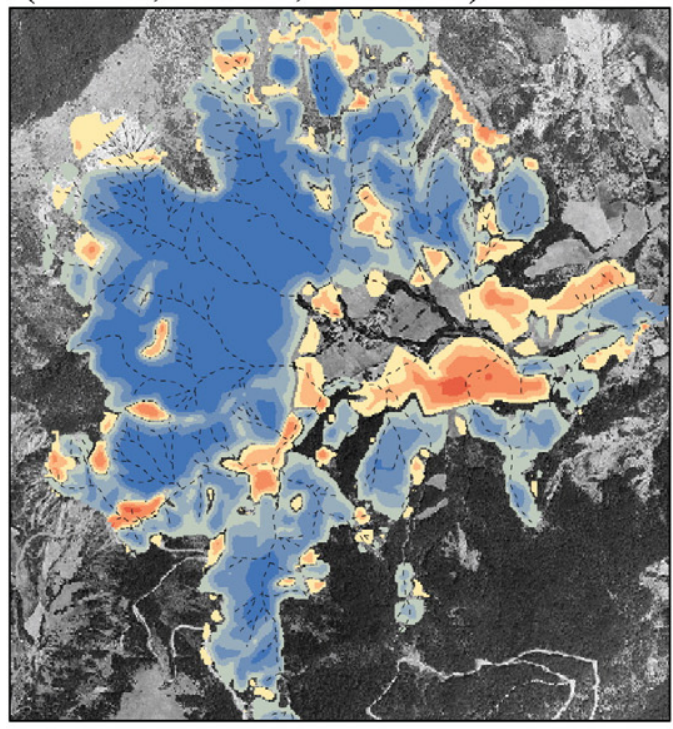

\section{c) Main Postglacial Infilling} (from 14,500 to 7000 cal. BP)

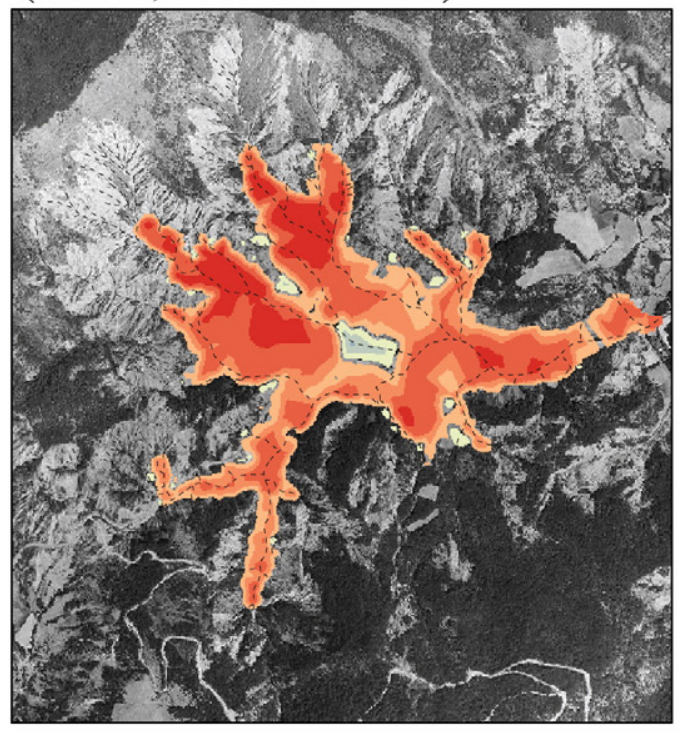

Thickness in metres :

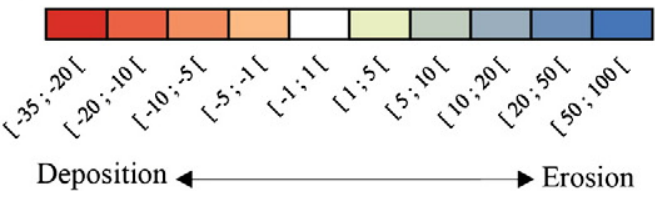

b) Topographic evolution from 14,500 cal. BP to Present

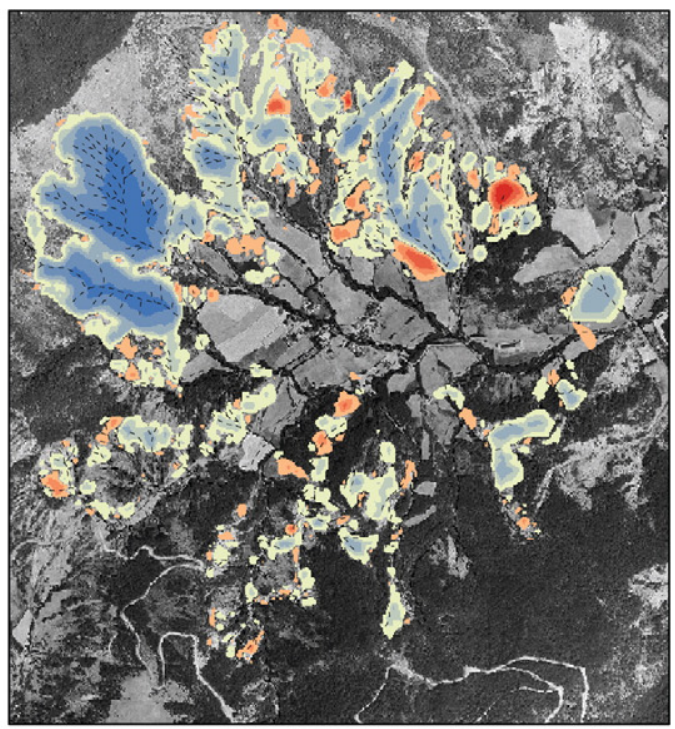

d) Linear post-MPI* incision (from 7000 cal. BP to Present)

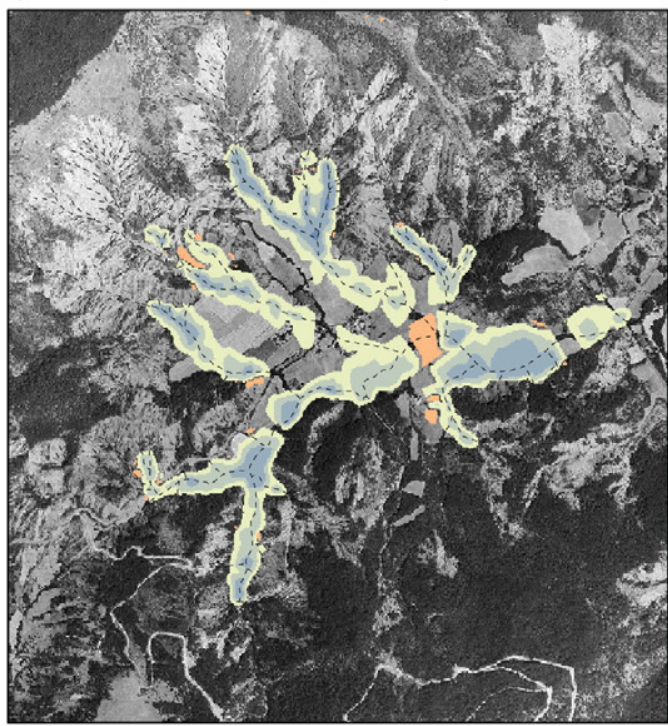

*MPI: Main Postglacial Infilling

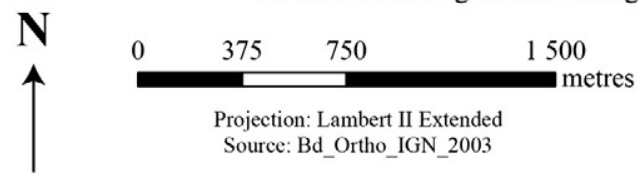




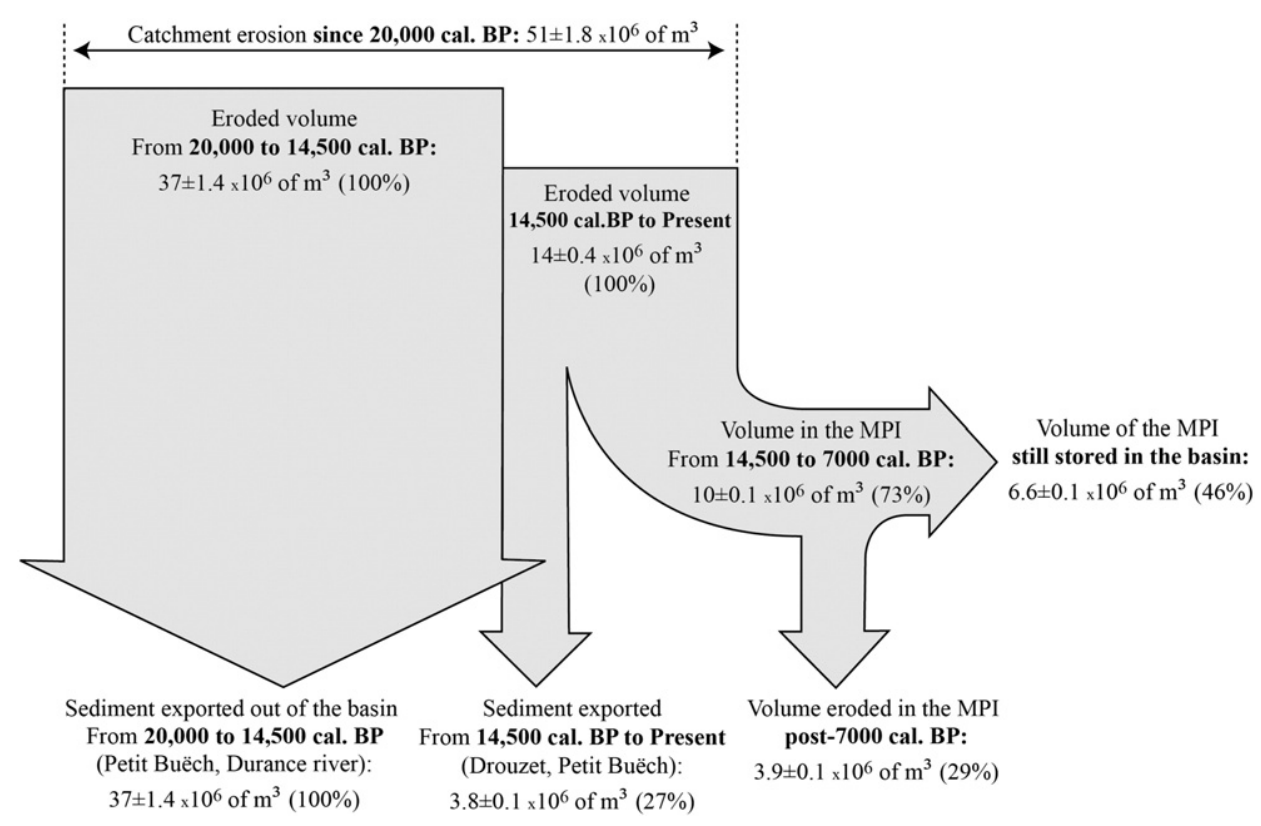

Fig. 10. Postglacial sediment budget of the Charanc catchment. Arrow thickness is proportional to volume.

a raster-DEM of relative surface above and below the initial surface. We will focus on the relative sediment budgets of each compartment rather than the absolute volumes. The quantification of the sediment budget is punctual in time because palaeotopography modelling can only be conducted on a few paleaogeomorphic states of the surface characterised as key dates in the field (see Section 2).

\section{Results}

\subsection{Palaeotopographic reconstructions}

Fig. 8 presents the four reconstructed palaeotopographies of the Charanc catchment. At the MIS-2 (Fig. 8a), slopes were regularised by thin accumulation glacis covering the sub-stratum. By about 14,500 cal. BP (Fig. 8b), terminations of the MIS-2 glacis had been partially eroded and the sub-stratum cropped out in the valley bottom. Around $7000 \mathrm{cal}$. BP (Fig. 8c), numerous small watersheds became active correlatively with the MPI phase. At present, these watersheds are well developed and the widespread MPI deposits incised by streams (Fig. 8d).

\subsection{Spatial distribution of Postglacial erosion and deposition}

Fig. 9a highlights the vast extent of the surfaces affected by erosion processes at the beginning of the Lateglacial period. On the upper part of the catchment, deep steep rills developed, preferentially on southfacing slopes. Fig. 9b depicts the very large extent of rills since the Early Holocene, and also the enlargement of numerous small torrential watersheds. Fig. 9c depicts the footslopes buried by the MPI. Deposits are very thick upstream (between 20 and $35 \mathrm{~m}$ ) and thickness decreases downstream. Finally, Fig. 9d illustrates the linear incision of the streams that affected the MPI. At present, streams are deeply entrenched in these deposits (10 to $15 \mathrm{~m}$ below the MPI surface).

\subsection{Sediment budgets}

Results of sediment budget calculations with the error margins are synthesised in Fig. 10. Between 20,000 and 14,500 cal. BP, 37 million $\mathrm{m}^{3}$ of sediments were eroded from the hillslopes. This eroded material was totally exported out of the catchment without intermediate storage. This sediment load did not accumulate in the Drouzet downstream of the Charanc. This entire volume of sediment was exported much further downstream to the trunk valleys of the Petit Buëch and Durance Rivers. Between 14,500 cal. BP and the Present, 14 million $\mathrm{m}^{3}$ of sediment were eroded at the expense of the periglacial glacis remnants and the marly substrate. 73\% (i.e., 10 millions of $\mathrm{m}^{3}$ ) of the eroded material was stored in fan-shaped MPI deposits. At the present time, 6 million $\mathrm{m}^{3}$ of MPI deposits (46\% of the eroded volume) are still stored in the catchment. A total of 8 million $\mathrm{m}^{3}$ of sediments (Fig. 10) have thus been exported out of the Charanc catchment since 14,500 years. Of this, about $50 \%$ originated from the MPI deposit and the other 50\% derived from erosion of the marly slopes. Assuming homogeneity of the eroded material and taking account of the bulk density estimated for the "Black Earths" by Mathys et al. (1996), which corresponds to $2.65 \mathrm{t} / \mathrm{m}^{3}$ from erosion of the marly sub-stratum and $1.3 \mathrm{t} / \mathrm{m}^{3}$ from erosion of a weathered marly deposit, we have estimated the following annual specific erosion rates (Fig. 11)

- on slopes (volume eroded multiplied by $2.65 \mathrm{t} / \mathrm{m}^{3}$ ): between 98 and $111 \mathrm{t} / \mathrm{ha} / \mathrm{yr}$ for the period 20,000-14,500 cal. BP and between 17 and $20 \mathrm{t} / \mathrm{ha} / \mathrm{yr}$ since $14,500 \mathrm{cal}$. BP.

- within the MPI deposits (volume incised multiplied by $1.3 \mathrm{t} / \mathrm{m}^{3}$ ): between 3 and 4 t/ha/yr from 7000 cal. BP to Present.

\section{Discussion}

From around 20,000 to 14,500 cal. BP, the weakly cohesive and easily reworkable periglacial formations that accumulated during the MIS2 were eroded and the sediment exported out of the catchment (Figs. 9, $10,11)$. The high slope sensitivity to erosion processes was probably reinforced as a result of an uneven protection by vegetation (Digerfeldt et al., 1997; Muller et al., 2007). This hypothesis is supported by the computed specific erosion rate for this period (103 t/ha/yr) which is comparable to rates measured in the field on denudated marls in the Middle Durance catchment (ca.100 t/ha/yr, Alary, 1998; Bufalo et al., 1990; Mathys et al., 1996, 2003; Olivry and Hoorelbeck, 1990). A more humid phase in Western Europe associated with the Pleistocene to Lateglacial transition (Harrison and Digerfeldt, 1993; Magny and Ruffaldi, 1995; Reed et al., 2001) was presumably responsible for this massive sediment export. This is in agreement with Vandenberghe (1995), who argued that 
at the scale of one glacial/interglacial cycle, major sedimentation influx is primary climatically-driven.

From 14,500 to Present, even though the amount of sediment eroded at the expense of the surrounding hillslopes was only $50 \%$ compared to the early Lateglacial period (Fig. 10), the volume of sediment transferred (tens of millions of $\mathrm{m}^{3}$ ) is very important, thus illustrating the sensitivity of these slopes to erosion. The main sediment supplier was the marly substrate, which was dissected by numerous small gullies. Forest conquest increasingly operated as a protective agent against slope erosion. Sancho et al. (2008) have suggested this forest expansion to explain sediment storage in alluvial valley bottoms in northwestern Spain in the early Holocene. The specific determinations carried out on preserved sub-fossil trees and charcoals buried in the MPI (Rosique, 1994, 1996) indicate the presence of Pinus sylvestris type vegetation, Salix and Ericaceae. Hence, slopes were occupied by sparse open woodlands composed of durably pioneering species that colonised the

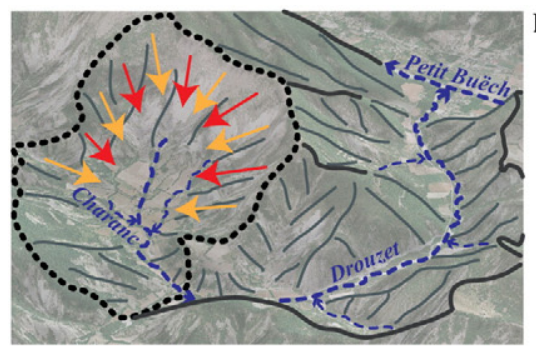

From 20,000 to $14,500 \mathrm{cal}$. BP

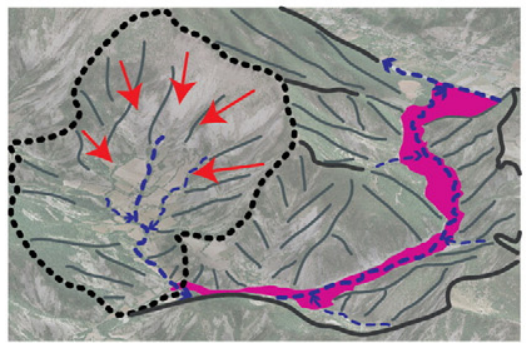

From 14,500 to $9000 \mathrm{cal}$. BP

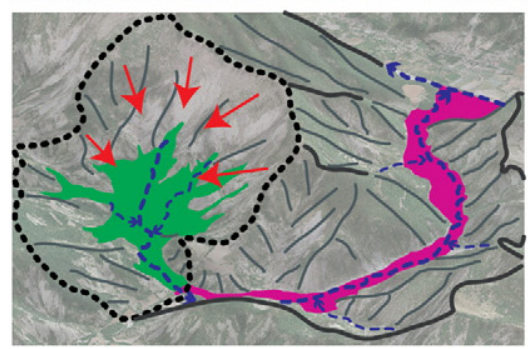

From 9000 to $7000 \mathrm{cal}$. BP

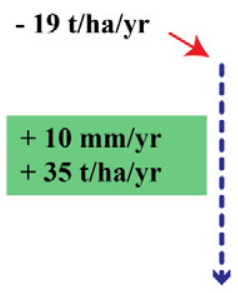

From 7000 cal. BP to Present

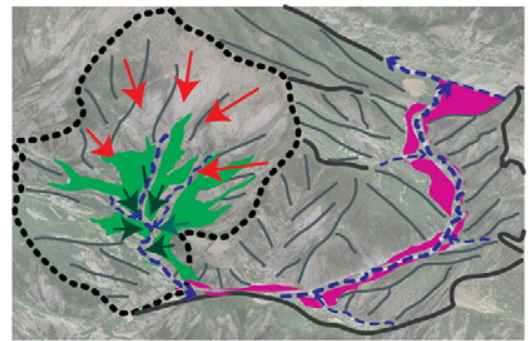

Sedimentary sources:

$\rightarrow$ MIS-2 cone-glacis

$\longrightarrow$ Marly substratum

$\longrightarrow$ MPI fan-shaped deposits
Transport regime:

$\rightarrow \rightarrow$ Torrential

Sediment sink:

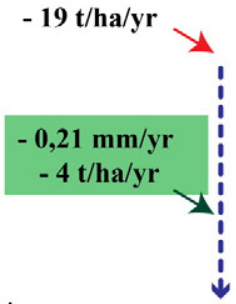

Fig. 11. Spatio-temporal source-to-sink characterisation and computed mean specific erosion and accumulation rates in the Charanc catchment. often-flooded valley bottoms. Numerous levels of charcoal in the MPI suggest a high frequency of occurrence of fires concomitant with detrital events between 15,000 and 12,500 cal. BP, between 11,800 and 11,200 cal. BP, and between 11,000 and 9700 cal. BP (Boutterin et al., 2008). These episodes of high fire frequency could have maintained soil instability or at least contributed to rapid acceleration of erosion. The driest periods in the western Mediterranean (Jalut et al., 2009) may have promoted triggering of fires of extremely flammable pine forests. Mean specific erosion rates decreased from 103 to 19 t/ha/yr during this period. Field measurements (e.g., Mathys et al., 1996) demonstrate that reductions in erosion rates are correlated with the spatial extent of the vegetation cover.

Between 14,500 and $7000 \mathrm{cal}$. BP, the spatiotemporal variability of the deposits enables the identification of two periods (Fig. 10). During the Lateglacial, river discharges were high enough to assure downstream export of fine-grained material out of the Charanc catchment to the Drouzet. This sediment transfer could correspond to a favourable phase of regular precipitation. Footslope storage of eroded material around $9000 \mathrm{cal}$. BP could indicate a change towards a regime of higher precipitation irregularity. A hypothesis of extremely intense short rain events, capable of generating these widespread deposits on footslopes, may also be invoked. However, sediment transport took place over relatively short distances. As discharge declined and sediment concentration increased, the transport dynamics could have changed quickly to one of deposition. From $7000 \mathrm{cal}$. BP to Present, the main prevailing geomorphic process has been that of sediment export from the Charanc catchment to larger downstream fluvial sinks. Roughly one-third of the MPI sediment volume has been eroded by streams (Fig. 10). The increase in sediment load and discharge ratio at the origin of the entrenchment of the streams may be interpreted as: (1) a reduction of bedload correlative with the development of forested brownish soils from 7000 cal. BP to 5000 cal. BP (Jorda et al., 2002); (2) an increase in precipitation; but this hypothesis is not supported by the very dry climatic conditions recorded by low lake levels in the southern Alps (Magny et al., 2002; Muller et al., 2012); (3) a change to a more regular precipitation regime with less thunderstorms. The question that may be posed here is whether the deep $10 \mathrm{~m}$ incision of the Charanc has generated, or not, over the last 7000 years, a regime torrential enough to be characterised by constant export of incoming sediment.

Between 20,000 cal. BP and the Present, mean specific erosion rates on slopes ranged from 0.17 to $0.21 \mathrm{~mm} / \mathrm{yr}$. Obviously, these average values mask significant temporal variability. Intermediate storage deposits such as the MPI, which are quite extensive in the Provence region, have also been notable sediment suppliers since $7000 \mathrm{cal}$. BP. The $5.2 \mathrm{~km}^{2}$ Charanc catchment has supplied around 5 million $\mathrm{t}$ of sediments to larger fluvial systems (Fig. 10) and around 8.3 million tof easily re-workable sediment are still available in this catchment, and thus provide an important source to feed the downstream sediment cascade in the future.

\section{Conclusion}

The study has demonstrated that geomatic GIS-based approaches open up new prospects for field research aimed at reconstructing palaeo-environments. Indeed, palaeotopographic modelling enables consideration of the geometric evolution of river catchments when sediment budget variations are quantified over time and space. The use of such GIS-based techniques coupled with previous radiocarbon age determinations highlighted three main periods in the geomorphic and sediment budget history of the small sub-Alpine Charanc catchment during the course of the Postglacial. Between 20,000 and $14,500 \mathrm{cal}$. BP, sediment eroded within the catchment was entirely exported downstream to the higher-order Drouzet catchment. A change to a sedimentation regime commenced at around $14,500 \mathrm{cal}$. BP. Between around $9000 \mathrm{cal}$. BP and $7000 \mathrm{cal}$. BP, footslopes were buried by MPI deposits at a rate of $6700 \mathrm{~m}^{3} / \mathrm{yr}$. 
Since 7000 cal. BP, the overall morphogenetic regime has been one of vertical incision, and MPI deposits have become a sediment source for downstream export. The sediment budget variations of the Charanc over the last 20,000 years illustrate source-to-sink fluvial sediment dynamics in relatively steep sub-Alpine catchments subject to Mediterranean bioclimatic conditions. Even though the Charanc catchment is only a small feeder catchment, it is representative of a large area of the Durance catchment (almost 14\% of the Durance catchment are composed of easily erodible "Black Earths"). This study has contributed to the analysis of the spatio-temporal variability of sediment fluxes from land to ocean, and has highlighted the dynamics of sediment storage and export in the long-term fluvial source-to-sink sediment cascade.

\section{Acknowledgements}

We are very grateful to three anonymous reviewers whose salient suggestions have greatly improved the manuscript.

\section{References}

Alary, C., 1998. Mécanismes et bilans de l'érosion dans un bassin versant méditerranéen aménagé: le cas de la Durance (S-E France). (PhD) Aix-Marseille 3 Univ, France (317 pp.).

Boutterin, C., Miramont, C., Muller, S.D., Valleteau, S., Edouard, J.L., 2008. Le role du feu dans l'histoire des paysages sudalpins de moyenne montagne entre 15000 et 7000 ans cal. BP: Approche méthodologique. In: Galop, D. (Ed.), Paysages et Environnement. De la reconstitution du passé aux modèles prospectifs, Besançon, pp. 159-169.

Bryan, R.B., Yair, A., 1982. Badland Geomorphology and Piping. Geo Books, Norwich (408 pp.)

Bufalo, M., Oliveros, C., Quelennec, R.E., 1990. L'érosion mécanique des Terres Noires dans la région du Buëch (Hautes Alpes, France). Géol. Alpine Mém. H.S. 15, 15-20.

Digerfeldt, G., De Beaulieu, J.L., Guiot, J., Mouthon, J., 1997. Reconstruction and paleoclimatic interpretation of Holocene lake-level changes in Lac de Saint-Léger Haute Provence, southeast France. Palaeogeogr. Palaeoclimatol. Palaeoecol. 136 (1-4), 231-258.

Förster, H., Wunderlich, J., 2009. Holocene sediment budgets for upland catchments: the problem of soilscape model and data availability. Catena 77 (2), 143-149.

French, H.M., 2007. The Periglacial Environment, 3rd ed. John Wiley \& Sons, Chichester, England (478 pp.).

Gallart, F., Solé, A., Puigdefábregas, J., Lázaro, R., 2002. Badland systems in the Mediterranean. In: Bull, J.L., Kirkby, M.J. (Eds.), Dryland Rivers: Hydrology and Geomorphology of Semi-arid Channels. Wiley, Chichester, pp. 299-326.

Gautier, E., 1992. Recherches sur la morphologie et la dynamique fluviales dans le bassin du Buëch (Alpes du Sud). (PhD thesis) Paris-X-Nanterre Univ (439 pp.).

Giorgi, F., Lionello, P., 2008. Climate change projections for the Mediterranean region. Glob. Planet. Chang. 63, 90-104.

Harrison, S.P., Digerfeldt, G., 1993. European lakes as palaeohydrological and palaeoclimatic indicators. Quat. Sci. Rev. 12 (4), 233-248.

Imbert, G., Kerambrun, P., Degiovanni, C., 1999. Hydrodynamics and sedimentation patterns linked to anthropogenic inputs into a Mediterranean littoral basin. C. R. Acad. Sci. 329 (3), 205-209.

IPCC, Kostaschuck, R.A., MacDonald, G.M., Intergovernmental Panel on Climate Change, 2007. Climate Change 2007 - The Physical Science Basis. Cambridge University Press, Cambridge.

Jalut, G., Dedoubat, J.J., Fontugne, M., Otto, T., 2009. Holocene circum-Mediterranean vegetation changes: climate forcing and human impact. Quat. Int. 200 (1-2), 4-18.

Jorda, M., Rosique, T., Évin, J., 2000. Données nouvelles sur l'âge du dernier maximum glaciaire dans les Alpes méridionales françaises. C. R. Acad. Sci. (Earth and Planetary Sciences) 331, 187-193.

Jorda, M., Miramont, C., Rosique, T., Sivan, O., 2002. Evolution de l'hydrosystème durancien (Alpes du Sud, France) depuis la fin du Pléniglaciaire supérieur. In: Bravard, J.-P., Magny, M. (Eds.), Histoire des rivières et des lacs de Lascaux à nos jours. Errance, Paris, pp. 239-249.

Kaiser, K.F., Friedrich, M., Miramont, C., Kromer, B., Sgier, M., Schaub, M., Boeren, I., Remmele, S., Talamo, S., Guibal, F., Sivan, O., 2012. Challenging process to make the Lateglacial tree-ring chronologies from Europe absolute - an inventory. Quat. Sci. Rev. 36, 78-90.

Macaire, J.J., Bellemlih, S., Di-Giovanni, C., De Luca, P., Visset, L., Bernard, J., 2002. Sediment yield and storage variations in the Negron River catchment (South-Western Parisian basin, France) during the Holocene period. Earth Surf. Process. Landforms 27, 991-1009.
Magny, M., Ruffaldi, P. 1995. Younger Dryas and early Holocene lake level fluctuations in the Jura Mountains, France. Boreas 24 (2), 155-172.

Magny, M., Miramont, C., Sivan, O., 2002. Assessment of the impact of climate and anthropogenic factors on Holocene Mediterranean vegetation in Europe on the basis of palaeohydrological records. Palaeogeogr. Palaeoclimatol. Palaeoecol. 186 (1-2), 47-59.

Mathys, N., Brochot, S., Meunier, M., 1996. Erosion of the Terres Noires (Black Earth) in the southern French Alps: a contribution to an assessment of mean annual values (Draix experimental catchment areas). Rev. Géogr. Alpine 84 (2), 17-27.

Mathys, N., Brochot, S., Meunier, M., Richard, D., 2003. Erosion quantification in the small marly experimental catchments of Draix (Alpes de Haute Provence, France). Calibration of the ETC rainfall-runoff-erosion model. Catena 50 (2-4), 527-548.

Meade, R.H., 1982. Sources, sinks, and storage of river sediments in the Atlantic drainage of the United States. J. Geol. 90, 235-252.

Miramont, C., 1998. Morphogenèse, activité érosive et détritisme alluvial holocènes dans le bassin de la moyenne Durance. (PhD) Aix-Marseille I Univ (286 pp.).

Miramont, C., Boutterin, C., Sivan, O., Bruneton, H., Mantran, M., 2008. Grandes séquences et principales ruptures morphogéniques en Haute Provence - les complexes sédimentaires des petits organismes torrentiels de moyenne Durance. Cahiers de Paléoenvironnement - Collection Edytem, vol. 6 145-154

Muller, S.D., Nakagawa, T., De Beaulieu, J.-L., Court-Picon, M., Carcaillet, C., Miramont, C. Roiron, P., Boutterin, C., Ali, A.A., Bruneton, H., 2007. Post-glacial migration of silver fir (Abies alba Mill.) in the south-western Alps. J. Biogeogr. 34, 876-899.

Muller, S.D., Miramont, C., Bruneton, H., Carré, M., Sottocornola, M., Court-Picon, M., De Beaulieu, J.L., Nakagawa, T., Schevin, P., 2012. A palaeoecological perspective for the conservation and restoration of wetland plant communities in the central French Alps, with particular emphasis on Alder Carr vegetation. Rev. Palaeobot. Palynol. 171, 124-139.

Nadal-Romero, E., Martínez-Murillo, J.F., Vanmaercke, M., Poesen, J., 2011. Scale-dependency of sediment yield from badland areas in Mediterranean environments. Prog Phys. Geogr. 35 (3), 297-332.

Notebaert, B., Verstraeten, G., Rommens, T., Vanmontfort, B., Govers, G., Poesen, J., 2009. Establishing a Holocene sediment budget for the River Dijle. Catena 77 (2), 150-163.

Olivry, J.C., Hoorelbeck, J., 1990. Erodabilité des terres noires de la vallée du Buech (France, Alpes du Sud). ORSTOM vol. XXV (1-2), 95-110.

Peucker, T.K., Fowler, R.J., Little, J.J., Mark, D.M., 1978. The triangulated irregular network. Symposium on DTMs, Am. Soc. of Photogramm./Am. Congr. of Surv. And Mapp. St Louis, Mo (8 pp.).

Reed, J.M., Stevenson, A.C., Jugglins, S., 2001. A multi-proxy record of Holocene climatic change in southwestern Spain: the Laguna de Medina, Cádiz. Holocene 11 (6), 707-719.

Rosique, T., 1994. Les gisements de bois fossiles conservés dans les formations détritiques tardi- et postglaciaires du bassin du Buëch (Hautes Alpes): interprétation géodynamique et paléoécologique. C. R. Acad. Sci., Paris 319 (II), 373-380.

Rosique, T., 1996. Morphogenèse et évolution des paléoenvironnements alpins de la fin des temps glaciaires au début de l'Holocène: l'exemple de la moyenne Durance (Alpes françaises du Sud). (PhD) Aix-Marseille I Univ (288 pp.).

Rosique, T., 1997. Detritism and morphogenesis at the end of Würm in the Southern French Alps (Middle Durance). Quaternaire 8 (1), 39-48.

Rosique, T., 2004. La dernière phase glaciaire de la moyenne Durance (région de Gap à Sisteron): bilan des recherches, dernières conclusions chronologiques. Méditerranée 102, 25-36.

Rovera, G., Robert, Y., 2005. Conditions climatiques hivernales et processus d'érosion périglaciaires dans les badlands marneux de Draix (800 m, Alpes du Sud, France) Géog. Phys. Quatern. 59 (1), 31-48.

Sancho, C., Peña, J.L., Muñoz, A., Benito, G., McDonald, E., Rhodes, E.J., Longares, L.A., 2008. Holocene alluvial morphopedosedimentary record and environmental changes in the Bardenas Reales Natural Park (NE Spain). Catena 73 (3), 225-238.

Sivan, O., 2002. Activité érosive et évolution des paléoenvironnements alpins postglaciaires. (PhD) Étude dendrogéomorphologique des gisements de troncs subfossiles dans les Alpes du Sud.Aix-Marseille I Univ (274 pp.).

Sivan, O., Miramont, C., 2008. Les variations temporelles et spatiales de la morphogenèse postglaciaire des fonds de vallons sud-alpins. L'exemple du bassin versant du Drouzet (Hautes-Alpes, France). Quaternaire 19 (3), 229-238.

Torri, D., Poesen, J., Calzolari, C., Rodolfi, G., 2000. Badlands in changing environments. (Special Issue) Catena 40 (2) (250 pp.).

Vandenberghe, J., 1995. Timescales, climate and river development. Quat. Sci. Rev. 14 (6), 631-638.

Verstraeten, G., Rommens, T., Peeters, I., Poesen, J., Govers, G., Lang, A., 2009a. A temporarily changing Holocene sediment budget for a loess-covered catchment (central Belgium). Geomorphology 108, 24-34.

Verstraeten, G., Lang, A., Houben, P., 2009b. Human impact on sediment dynamics quantification and timing. Catena 77, 77-80.

Ward, P., van Ralen, R., Verstraeten, G., Renssen, H., Vandenberghe, J., 2009. The impact of land use and climate change on late Holocene and future suspended sediment yield of the Meuse catchment. Geomorphology 103, 389-400.

Wolf, D., Faust, D., 2013. Holocene sediment fluxes in a fragile loess landscape (Saxony, Germany). Catena 103, 87-102. 